\title{
INCIDENCE AND MORPHOLOGY OF THE THYMUS IN HAIRLESS GUINEA-PIGS
}

J. KAMAN

Department of Pathological Morphology and Parasitology, University of Veterinary Science, 612 42 Brno

Received January 8, 1986

\begin{abstract}
$\mathrm{K}$ a $\mathrm{m}$ a $\mathrm{n} \mathrm{J} .:$ Incidence and Morphology of the Thymus in Hairless Guinea-Pigs. Acta vet. Brno,56,1987:19-30.

Occurrence and morphology of the thymus was studied in 9 hairless guinea-pigs of various ages, weighing 180$275 \mathrm{~g}$, and in 5 intact controls from the same breeding colony of identical ages and body mass; two further controls weighing 320 and $480 \mathrm{~g}$, were from a different colony. In 1979, hairless guinea-pigs originated in a colony of laboratory animals (USOL /Institute of Sera and Vaccines/, Bohumile, Czechoslovakia); it was an accidental discovery of a mutation of one hairless male. By further inbred and outbred breeding a "hairless" line was obtained.

In all hairless guinea-pigs not only the thymus was well-developed (a derivative of the III. pharyngeal pouch), but also the noduli thymici accessorii (derivatives of the IV. pharyngeal pouch). In view of the contradictory literature data on topography of the thymus in guinea-pig we confirmed and determined its precise localization in the regio cervicalis (lobus cervicalis dexter et sinister). The gross findings were confirmed histologically. Other derivatives of the III. and IV. pharyngeal pouches were also morphologically intact. Both good survival rate and haematology examinations of the animals support the notion that these mutants are not immunologically deficient. They carry the gene for hairlessness without the athymic trait; they are therefore suitable for experiments where hairlessness is a desirabl trait.
\end{abstract}

Hairlessness, guinea-pig, thymus, noduli thymici accessorii, anatomu, histology:

In literature, not only hairless mice but also hairless guinea-pigs have been connected with deficient development or complete absence of the thymus or its substitute, a thymus-like lymphatic tissue and impaired immunocompetence.

A colony of hairless guinea-pigs developed at the Institute of Sera and Vaccines - OSOL, Bohumile (Czechoslovakia) from an accidentally discovered mutation of one hairless male. This animal was mated to 2 non kin 


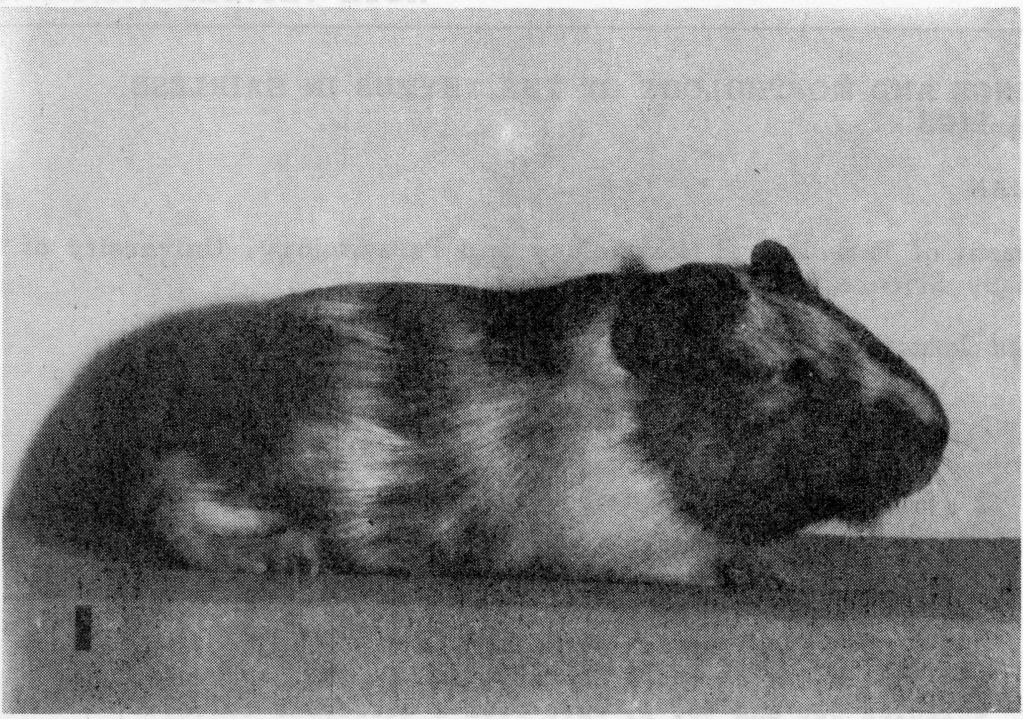

Fig. 1. A control guinea-pig with intact hair coat.

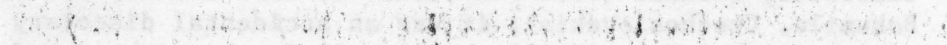

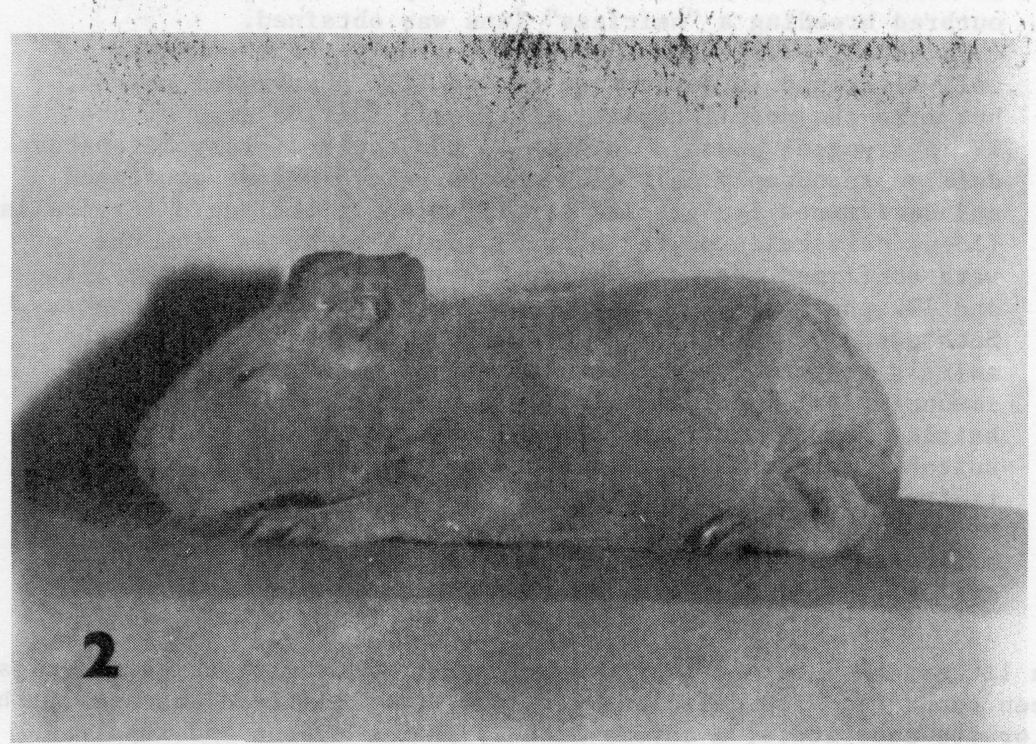

Fig. 2. A hairless guinea-pig carrying the gene for hairlessness. 
females with intact hair cover. In the resulting litters the hairless progeny occurred at a ratio $1: 3$. Further inbred and outbred husbandry produced the "hairless". 1ine.

$0^{\prime} \mathrm{D} \circ \mathrm{n} \circ \mathrm{g} \mathrm{h}$ u a and $\mathrm{R}$ e e d (1981) failed to find the thymus or any comparable structure even in newborn hairless immune-deficient guineapigs in which it was most likely to be found at the height of its development (Co o p e r and S c h $111 \mathrm{e}$ 1975). The question of abnormal development of the thymus in hairless mice was explored by $W$ o $r-$ $t i \mathrm{~s}$ et al. (1971). This organ may also be found as dysplastic or identified as a "rudiment of a thymus in athymic hairless mouse" ( $\mathrm{H} \circ \mathrm{l} \mathrm{u} \mathrm{b}$ et a1. 1975). A "thymus-like lymph node" was found in the cervical region, where normally thymus would be present, of hairless mice (H $\mathrm{s}$ et al. 1975).

For a more complex evaluation of the above-mentioned hairless guineapig colony from the viewpoint of immunocompetence of the organism we found important to verify the existence or the stage of development and morphology of the thymus in these animals with respect to possible substitution of this organ by a thymus-like lymphatic tissue.

The basic data on anatomy of the thymus in guinea-pigs are given by $C \circ h \mathrm{r} s$ et al. (1958), $\mathrm{N}$ e $\mathrm{j}$ e d 1 y (1965) and $\mathrm{C} \circ \circ \mathrm{p}$ e $\mathrm{r}$ and $\mathrm{S}$ c h $\mathrm{i} 1 \mathrm{l}$ e r (1975). However, contradictory data exist as to the principal question, i.e. topography of the gland: the authors localize it to two different regions.

G o o d a 11 (1905) investigated the postnatal changes and effects of castration upon the thymus in guinea-pigs; I $z$ a $r \mathrm{~d}$ (1966) followed the ultrastructure of thymic reticulum and. M a n d e 1 , (1969) studied the epithelfal cells and lymphapolesto th the thytuc cortex of gutnea-pigs.

In the present study, besides the hatrless animals also a group of hatry guinea-pigs 'from the same breeding colony and two subject from a different colony were included in order to compare the findings and to ellucidate the topography of the thymus.

\section{Materials and Methods}

In the present study, 9 hairless guinea-pigs aged 4, 5 and 7 weeks (weighing 180 to $275 \mathrm{~g}$ ) were used. Morphology and topography of the thymus was studied in situ after exsanguination by cardiac puncture. A routine preparation technique and a magnifier were used. Thymus, accessory thymus and adjacent organs (gl. thyroidea, gl. parathyroidea, lymph nodes and salivary glands) were dissected out, identified and histologically examined in paraffin sections stained with $\mathrm{HE}$. The findings were documented by photomacro- and micrographs and a semischematic drawing.

Five subjects with normal hair coat of the same ages, i.e. 4,5 and 7 weeks and of similar body mass served as controls along with further 2 animals (weighing 320 and $480 \mathrm{~g}$ ) from a different breeding colony.

\section{Results}

Similar to controls, all hairless guinea-pigs had a fully developed thymus situated in the cervical region, approximately in its middle third. The organ was easily accessible after dissecting off the skin, platysma and a small amount of connective tissue. The thymus was a paired organ forming two flattened, oval lobes attached to both sides of the trachea. The medial margin of each lobe accompanied the trachea, $\mathrm{m}$. sternohyoideus and $\mathrm{m}$. 


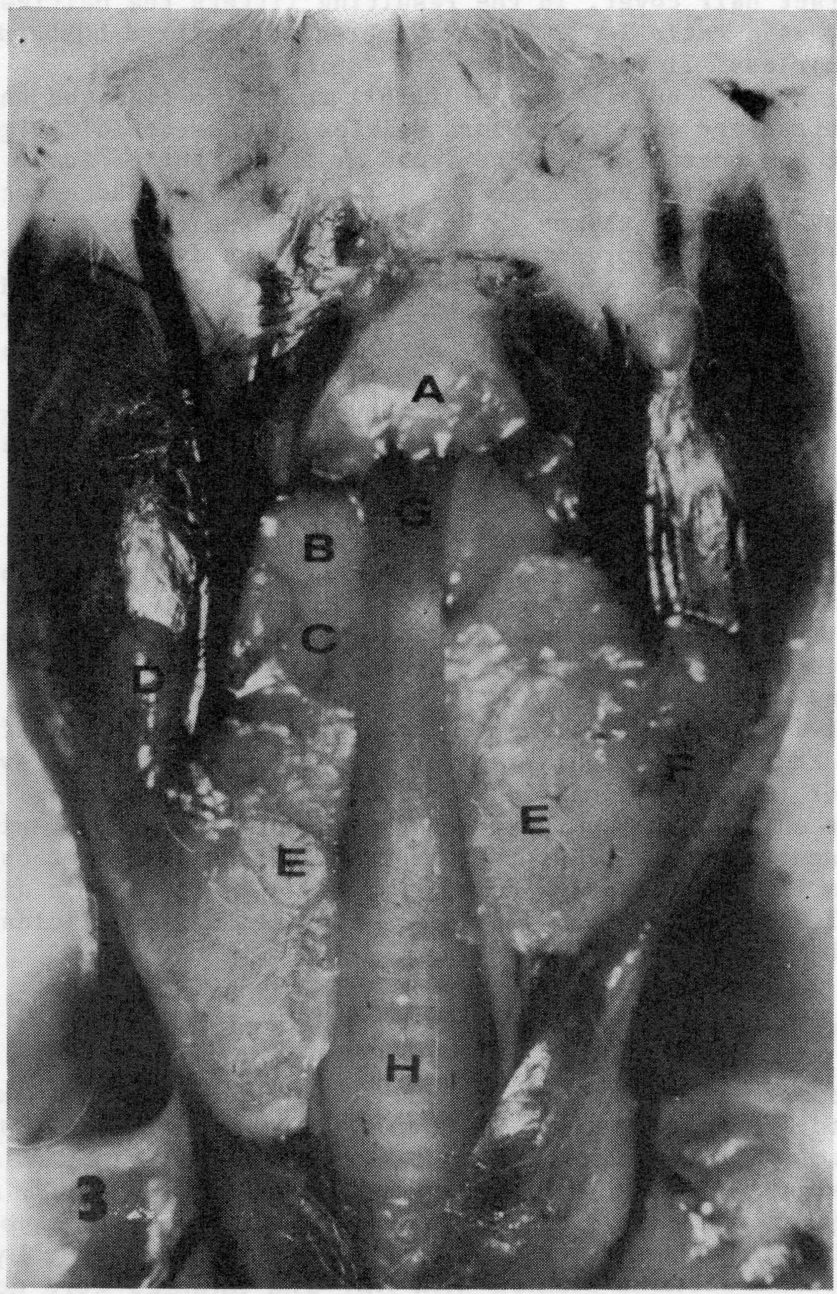

Fig. 3. Ventral view of the cervical region of a healthy guinea-pig with well developed thymus. A-1ymphonodus mandibularis rostralis, Bglandula sublingualis monostomatica, C- glandula mandibularis, Dlymphonodus mandibularis caudalis, E-thymus, F- glandula parotis, G- musculus sternohyoideus et sternothyrnideus, H- trachea. 
sternothyroideus, its dorsal surface was attached to a. carotis communis, $v$. jugularis interna, truncus vagosympaticus and glandula thyroidea. The cranial, broader margin was apposed to glandula mandibularis. The lateral margin of the thymus in its cranial half was attached to the glandula parotis, its caudal half was free. The caudal, slightly wedged end in some animals partly embraced the ventral surface of trachea. Its conspicuous light pink-greyish or pink-yellow colour and delicate lobular structure with macroscopically visible stroma of connective tissue distinguished the thymus from the adjacent glandular organs.

The thymus occupied an area from the level of angulus mandibulae to $2 / 3$ to $3 / 4$ of cervical lenght towards manubrium sterni being about $7 \mathrm{~mm}$ apart from it. Variability of the caudal margin was given rather by displacement of its cranial end more rostrad caudal beyond the angulus mandibulae than by varying length of the thymus. In most cases, both lobes were evenly developed. The left lobe appeared somewhat longer in 2 hairless animals and in 1 control; the right lobe was longer only in 1 control animal. The lobes were situated symetrically, though sometimes the left lobe, rarely the right one, reached more caudad than the other one. The average length of the thymus in control animals was $15.5 \mathrm{~mm}$, width $7.9 \mathrm{~mm}$, in hairless guinea pigs 16.2 and $8.37 \mathrm{~mm}$, respectively (its thickness was $3.6 \mathrm{~mm}$ ). In hairless animals, the size of the thymus seemed to vary with the body mass of animals.

In two hairless individuals and one control, an accessory thymus, a derivative of the IV. pharyngeal pouch, was accidentally found (noduli thymici accessori). The structure $(2 \times 1 \mathrm{~mm})$ was difficult to resolve to the unaided eye. The accessory thymus was more or less incorporated in glandula thyroidea.

Microscopic findings fully confirmed the gross findings on thymus identity.

Histological sections of the thymus in hairless guinea-pigs revealed a typical picture of thymic lymphoreticular tissue conspicuously demarcated into the lighter medulla with a tree-like branching. The branches were surrounded with a dark, relatively thick cortex. The superficial division of the organ into lobules was not complete in histological sections. The interlobular fibrous connective tissue septa did not penetrate the whole cortical thickness to the medulla so that the lobules were not entirely separated from each other and at the basis they were connected to various degrees through their medulla.

The substrate of the thymic parenchyme, the epithelial reticulum, was quite evident. Its cells with conspicuous, large light nucleus were, however, in the cortical layer almost obscured by thymolymphocytes, particularly abundant near the lobular surface. Among them, the individual epithelial cells were visible. In the cortex, occasionally granulocytes and mitoses of thymolymphocytes were found.

In the medullar portion of the thymus, lymphocytes were substantially less abundant and thus the reticular cells rich in cytoplasm were more prominent. Thus the medulla appeared less compact than the cortex. In all animals, relatively numerous corpuscula thymi (Hassal's corpuscles) in various stages of development were disseminated, of various sizes from the simplest (corpusculum unicellulare thymi) to complex ones, visible by unaided eye.

The corpuscula thymi, obviously acidophilic, showed their typical structure, a number of them being in the stage a dystrophic process. The cell nuclei showed karyorrhexis, the cytoplasm became more acidophilic and formed small, colloid-like, strongly acidophilic droplets and hyaline mass. At sites of total cell destruction cystic formations occurred into which lymphocytes and granulocytes partly penetrated. Not infrequently the de- 


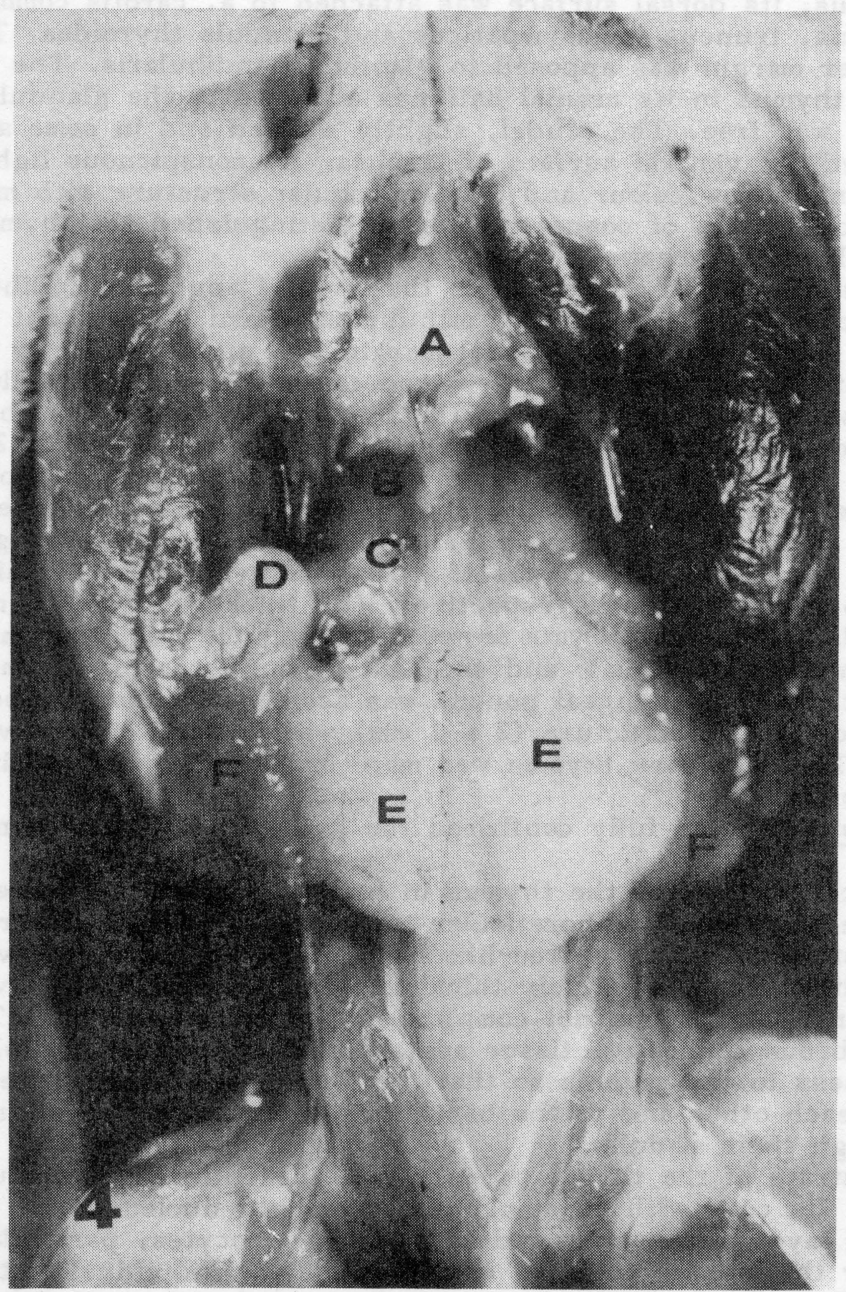

Fig. 4. Ventral view of the cervical region of a hairless guinea-pig with well developed thymus. For legend see Fig. 3 . 
generated corpusculum thymicum was isolated to great extent from the adjacent medulla and was sometimes connected with it only at sites where no dystrophic changes of cells were found.

In two animals a mild cumulation of fat cells in the interlobular spaces was observed, in one of these only a few fat cells in the lobular medulla were present. The findings of fat tissue were not age-dependent.

\section{Discussion}

The thymus in both control and hairless guinea-pigs was localized in the cervical region as described by Go o d a 11 (1905), C o h r s et al. (1958), I z a $\mathbf{r}$ (1966) and $C$ o o p e r and $S$ c h i l l e r (1975). In the light of these observations $\mathrm{N}$ e j e d l ý (1965) was not right to localize this organ in the thoracic cavity, dorsal to sternum.

Thymus is the basis of immunocompetence of the organism ( $G \circ 1$ ds $t$ e $\mathrm{i} \mathrm{n}$ and $\mathrm{Mc} K$ a $y$ 1969). This implies that various degrees of dysplasia or even aplasia of this organ interferes with both cellular and humoral immune system as demonstrated by experimental thymectomy ( $\mathrm{Y}$ u n i s et al. 1971).

In pertinent literature there are several papers on morphological and functional changes in hairless rats and especially hairless mice. On the other hand, the new mutant of guinea-pig with anomalous hair growth and immunodeficiency has only been described by $R$ e e d and $O^{\prime} D$ o $\mathrm{n}$ o $\mathrm{g} \mathrm{h}$ u e (1979). These hairless, immunodeficient subjects seem to be the result of a mutation that interferes with normal hair coat growth and with induction of mesenchymal tissues and formation of a normal thymus. The authors found thymic hypoplasia or aplasia. These animals also showed a deficiency in serum immunoglobulins that may be a primary defect or one related secondarily to thymic hypoplasia. Affected animals showed deficits in cell-mediated immunological responses as shown by delayed graft rejection and extreme susceptibility to viral, fungal and protozoan agents $\left(\mathrm{O}^{\prime} \mathrm{D} \mathrm{o}^{-}\right.$ $\mathrm{n} \circ \mathrm{g} \mathrm{h} \mathrm{u} e$ and $\mathrm{R}$ e e d 1981). The non-thymic lymphoid tissue of the lymph nodes, spleen and aggregated lymph nodules in the intestinal wall (Peyer's plaques) were anatomically intact in these animals. However, it was not possible to keep them alive for more than a few months.

Nevertheless, several more recent observations in $\mathrm{nu} / \mathrm{nu}$ mice ( $\mathrm{H}_{0}-$ $\mathrm{lu} \mathrm{b}$ et al. 1975; $\mathrm{H} \mathrm{s} \mathrm{u}$ et al. 1975; $\mathrm{H} \mathrm{O} \mathrm{l} \mathrm{u} \mathrm{b} \mathrm{et} \mathrm{al.} \mathrm{1978)} \mathrm{but}$ also in hairless guinea-pigs ( $\mathrm{O}^{\prime} \mathrm{D} \circ \mathrm{n} \mathrm{o} \mathrm{g} \mathrm{h} \mathrm{u}$ and $\mathrm{R}$ e e d 1981) indicate that athymia is not complete: in so-called athymic animals a rudimentary thymic tissue rather resembling the thymus of lower vertebrates than a fully-developed mammalian thymus ( $\mathrm{H}$ o $1 \mathrm{u} \mathrm{b}$ et al. 1975) may be encountered. In other cases, a modified deficient thymus may be present in various forms as small remnants of dense lymphatic tissue with differentiated thymic lymphocytes and in about 8 per cent as "thymic" epithelial cells near the left mediastinal lymphatic node mimicking the thymic tissue ( $\mathrm{H}$ o $1 \mathrm{u} \mathrm{b}$ et al. 1978). Similar structures have also been described by $W$ or $t$ i $s$ et al. (1971) in a nu/nu mouse, and by $O^{\prime} D \circ n \circ g h u$ and $R$ e e d (1981) in a hairless guinea-pig. In a nu/nu mouse, lobular lymphatic tissue histologically resembling the thymus with active proliferation of lymphocytes, histiocytes and reticular cells was found in the area of normal thymus localization ( $\mathrm{H}$ s $\mathrm{u}$ et al. 1975).

Our findings in hairless guinea-pigs are at variance with those of $\mathrm{O}^{\prime} \mathrm{D}$ o $\mathrm{n}$ o $\mathrm{g} \mathrm{h} \mathrm{u} \mathrm{e} \mathrm{and} \mathrm{R}$ e e d (1981). In all animals not only a fully developed thymus, a derivative of the III. pharyngeal pouch but also 


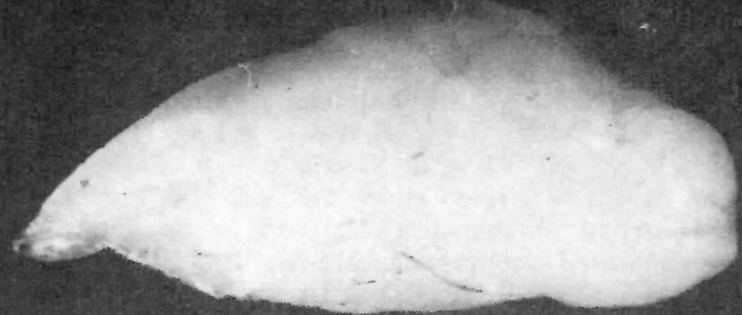

5

Fig. 5. Isolated thymus of a hairless guinea-pig.

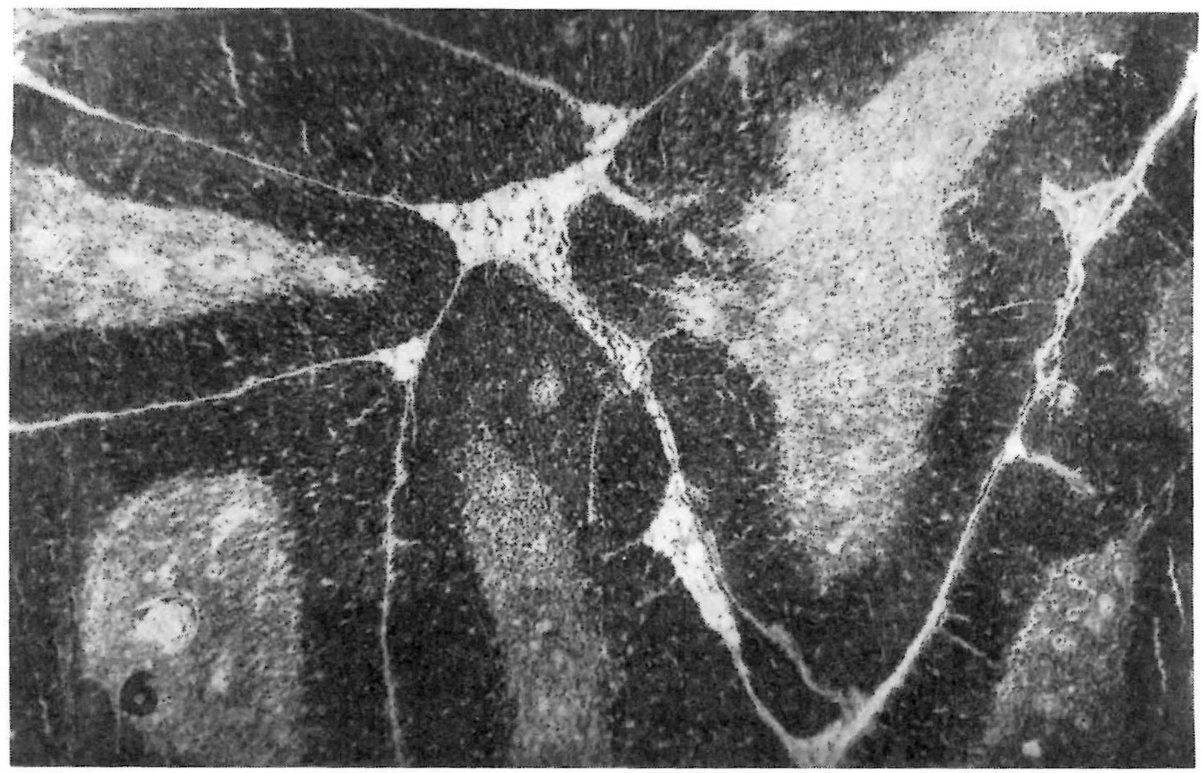

Fig. 6. Histological section of a hairless guinea-pig thymus revealing its typical structure. HE, magnification, $x 18$. 


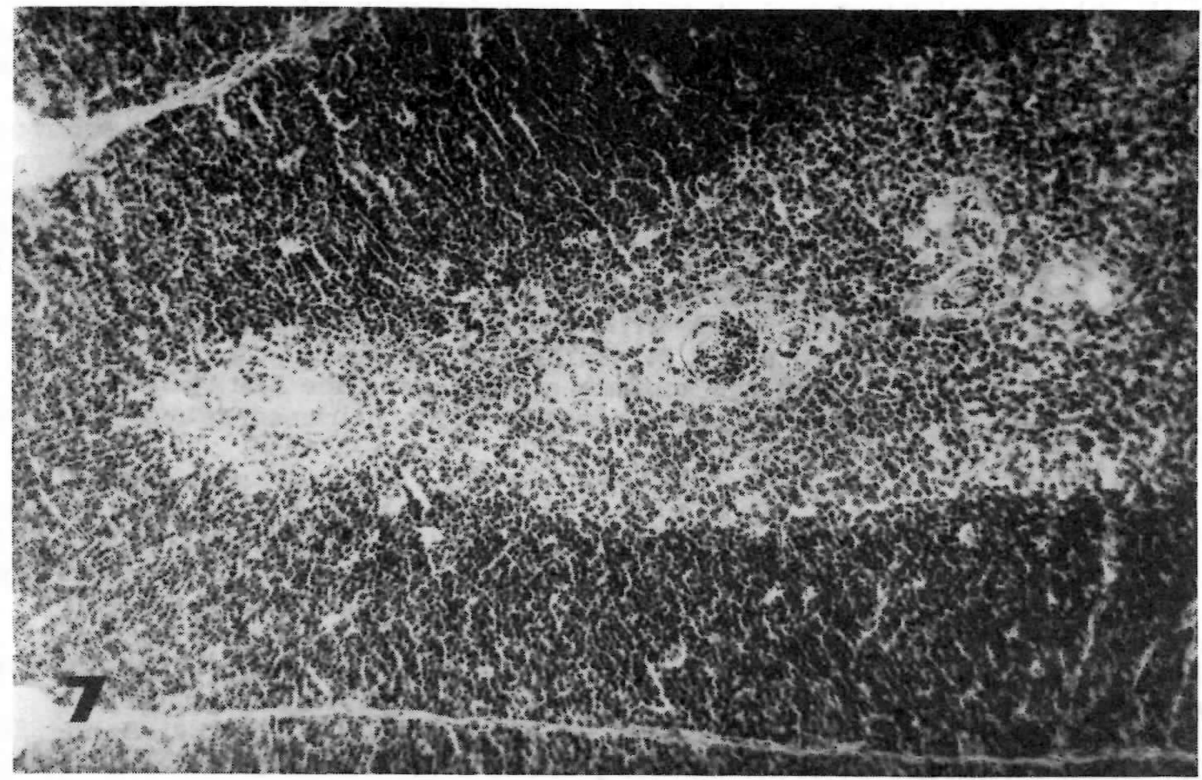

Fig. 7. Detail from Fig. 6. Well developed darker cortex and lighter medulla and the sharp line between them; corpuscula thymi of various stages of development and varying in size. HE, magnification, $x 64$.

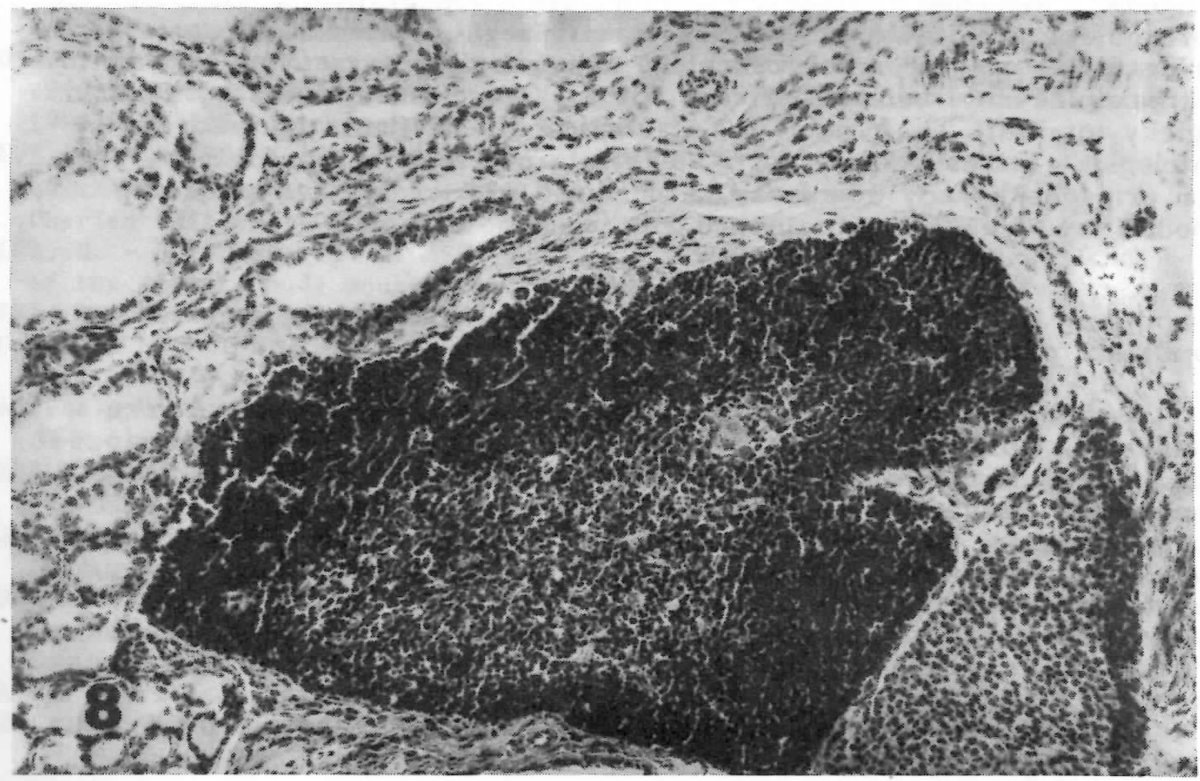

Fig. 8. Lobuli thymici accessorii in a hairless guinea-pig, incorporated in glandula thyroidea. HE, magnification, $x 64$. 
in a number of animals an accessory thymus originating from entoderm of the IV. pharyngeal pouch was detected. Morphologically intact were also the regional lymph nodes, salivary glands, thyroid and parathyroid glands. The fact that the animals survived well indicates a normal function of their immune system. Absence of immunodeficiency is supported by haematological findings in these subjects ( $P r$ a $v$ d personal communication).

The only defective system in our animals was the skin as manifested in defect of hair development (hereditary atrichia). This condition in our subjects was described by $\mathrm{H} \circ \mathbf{r} \mathbf{k}$ ý (1985, personal communication).

In conclusion, it is obvious that the guinea-pigs described and studied in the present paper differ entirely from the hairless mutants reported by $R$ e e d and $O^{\prime} D \circ n \circ g h u e$ (1979) and $O^{\prime} D \circ n \circ g h u$ and $R$ e e d (1981). In our case the mutants carry a gene for hairlessness. Therefore they are suitable for experiments in which hairlessness is a desired trait, e.g. in dermatology.

\section{K otázce existence a morfologie brzliku $u$ bezsrstých morčat}

Prozkoumali jsme výskyt a morfologii brzlíku u 9 bezsrstých morčat různých věkových skupin, hmotnosti 180 - $275 \mathrm{~g}, 5$ kontrolních morčat z téhož chovu, analogického věku a hmotnosti, a další 2 kontroly $z$ jiného chovu o hmotnosti 320 a $480 \mathrm{~g}$. Kolonie bezsrstých morčat vznikla v roce 1979 v chovu laboratorních zvírat Ustavu sér a očkovacích látek (USOL), Bohumile, CSSR z náhodně objevené mutace jednoho bezsrstého samce. Další cizorodou i příbuzenskou plemenitbou byla získána "bezsrstá" linie.

U všech bezsrstých morčat byl plně vyvinutý nejen thymus (derivát III. žaberní štěrbiny), ale i noduli thymici accessorii (derivát IV. žaberní štěrbiny). Vzhledem $\mathrm{k}$ rozporům $\mathrm{v}$ literatuře o topografii brzlíku $\mathrm{u}$ morčete upřesnuujeme a potvrzujeme jeho lokalizaci $v$ regio cervicalis (lobus cervicalis dexter et sinister). Makroskopické nálezy byly potvrzeny vyšetřením mikroskopickým. I ostatní derivátý III. a IV. žaberní štěrbiny byly morfologicky intaktní. To, že nejde o mutanty imunitně deficitní potvrzoval i hematologický status a skutečnost, že zvířata přežívala bez problémů. V našem př́ípadě jde tedy o mutanty nesoucí gen pro lysost. Zvířata jsou proto vhodná pro využití $v$ experimentu kde lysost je žádoucí.

К вопросу существования и морфологии тимусау бесшерсных морскыцх свинок

В содержании лабораторных животных института сыворотки и прививок, Богумиле, ЧССР, возникла в 1979 г. колония бесшерстных морскыцх свинок из случайно открытой мутации одного бесшерстного самца. В ходе дальнейшего чужеродного и родственного разведения получили "бесшерстную" линию. Проводили исследования наличия и морфологии тимуса y 9 упомянутых бесшерстных Свинок разных возрастных групп, массой $180^{\prime}-875$ г и 5 контрольных морскых свинок того же содержания, аналогичного возраста и массы и других 2 контрольных морскых свинок другого содержания, массой $320-480 \mathrm{r}$.

у всех бесшерстных морских свинок был полностью развит не только тимус (производное III жаберной щели), но и noduli thymici accessorii (производное IV. жаберной щели). Учитывая противоречи- 
вые литературные данные по топографии тимуса морских свинох, нами подтверждается его локализация в regio cervicalis (lobus cervicalis dexter et sinister). Макроскопические данные были подтверждены михроскопическими исследованиями. Остальные дериваты III и IV. жаберной щели были также морфологически интактными. То обстоятельство, что речь не идет об иммуно дефицитных мутантах, было потверждено гематологическим состоянием и фактом беспроблемного переживания животных. Следовательно, исследуемые нами мутанты принципиально отличались от описанных. Reed и O'Donoghue (1979) бесшерстных свинок. В нашем случае речь идет о мутантах с геном облысения. Животных поэтому можно использовать для эксперимента, в котором облысение желательно.

\section{Acnowledgement}

The author thanks associate professor J. Vařejčko for provision of the hairless animals and of photographs (Fig. 1 and 2) from the archive of the Department of Animal Husbandry and Genetics of the University of Veterinary Science in Brno.

\section{References}

COHRS, P. - JAFFE, R. - MEESSEN, H.: Pathologie der Laboratoriumstiere. Springer Verlag Berlin-Göttingen-Heidelberg, 1958.

COOPER, G. - SCHILLER, A.L.: Anatomy of the guinea pig. Harvard Univ. Press, Cambridge, Mass., 1975.

GOLDSTEIN, G. MacKAY, I.R.: The human thymus. W.H. Gree, St. Louis, Mo., 1969. Cit. In YUNIS, E.J. - STUTMAN, 0. - GOOD, R.'A.: Thymus, Immunity and autoimmunity. Annals N.Y. Acad. Sci., 183, 1971:205-220.

GOODALL, A.: The post-natal changes in the thymus of guinea-pigs, and the effect of castration on thymus structure. J. Physiol. (London), 32 , 1905: 191-198.

HOLUB, M. - ROSSMANN, P. - RYCHTER, Z. - VANECEK, R.: The dysplastic thymus of the mouse mutant nude. XLXth Morphological Congress. Symposia Charles University Prague, 1978: 305-312.

HOLUB, M. - ROSSMANN, P. - TLASKALOVA, H. - VIDMANOVA, H.: Thymus rudiment of the athymic nude mouse. Nature, 256, 1975: 491-3.

HORKY, D.: Personal communication, 1985.

HSU, CH.K. - WHITNEY, R.A. - HANSEN, C.T.: Thymus-like lymph node in nude mice. Nature, 257, 1975: 681-682.

IZARD, J.: Ultrastructure of the thymic reticulum in guinea pig. Anat. Rec., 155,1966 : 117-132.

MANDEL, T.: Epithelial cells and lymphopoiesis in the cortex of guinea-pig thymus. Anat. J. exp. Biol. med. Sci., 47, 1966: 153-155.

NEJEDLY, K.: Biologie a soustavná anatomie laboratornich zvírat. SPN, Praha, 1965.

O'DONOGHUE, J.L. - REED, C.: The hairless immune-deficient guinea pig. Immunologic Deffects Lab. Anim., Edit. Gershwin M.E. and Merchant B., New York, 1981.

PRAVDA, D.: Personal communication, 1985.

REED, C. - O'DONOGHUE, J.L.: A new guinea pig mutant with abnormal hair production and immunodeficiency. Lab. Animal Sci., 1979. Cit. in O'DONOGHUE, J.L. - REED, C., 1981. 
WORTIS, H.H. - NEHLSON, S. - OWEN, J.J.: Abnormal development of the thymus in "nude" mice. J. Exp. Med., 134, 1971: 681-692. 